\title{
A Case Study of New England Open Data Portals
}

\author{
Bonnie Paige* and Luanne Freund** \\ ${ }^{*}$ Colby College, bonnie.paige@colby.edu \\ **School of Information, University of British Columbia, luanne.freund@ubc.ca
}

\begin{abstract}
Open government data has proliferated across every level of government in the 2010s, but research has focused primarily on national or municipal portals, which may obscure the challenges faced in providing open government data in less densely populated areas. This research focuses on the cases of three US states- Maine, New Hampshire, and Vermont. We examine the stated goals of each portal and any policies related to their establishment or upkeep. We then examine the portals with regard to updating, reuse, organization and other factors. Of the three cases, Vermont's portal is moderately successful and continues to be used. New Hampshire's strategy of linking to data on agency websites is inconsistent, but the state law requiring data published to be in open formats does mean data is more open when it is provided. Maine's portal went dormant soon after its initial creation, and was fully taken down in the timeframe of this research. These cases illustrate that the establishment of a state portal alone does not guarantee that the portal will support the desired outcomes.
\end{abstract}

Keywords: Open Government Data, US states, open data portal, case study

Acknowledgement: We would like to thank Lisa Nathan for her valuable input in the early stages of this project.

\section{Introduction}

Open government is enacted through diverse initiatives, including the release of formerly closed government information, the provision of e-services, and the creation of platforms for deliberation (De Blasio \& Selva, 2016). This paper focuses on open government as achieved through proactive release of open government data (OGD). OGD is data collected by government organisations in the process of their work, that is made publicly available in a way that facilitates access and reuse. The topical coverage of datasets is extremely broad, including social statistics, transportation, meteorology, law, geography, patents and businesses (Ubaldi, 2013). Access to this data is usually provided through an open data portal, which serves as a central point of access and allows stakeholders to access the data most relevant to their needs, without restricting them to certain views of the data (Alonso et al., 2009; Attard, Orlandi, Scerri \& Auer, 2015). OGD is considered to be a valuable resource that can be used to improve public services, increase oversight of government 
finances, and inform citizens about the standards expected of government agencies (G8, 2013). OGD advocates argue primarily for its social and economic benefits, including transparency, commercial value, and participatory governance (Attard et al., 2015). Some have framed OGD from a public value perspective, arguing that the goal of government is to produce public value for members of society and that OGD can be a means of achieving this (Ubaldi, 2013; Harrison et al., 2012; Reddick, Chatfield, \& Puron-Cid, 2017). Without such a public value perspective, there are concerns that OGD initiatives could be viewed as "empty scaffolding", undertaken to satisfy minimal requirements of compliance or in the service of political agendas (Harrison et al., 2012).

In the United States (US), OGD was a major initiative of the Obama administration (Obama, 2009; Obama, 2013). With roots going back to the 2007 Sebastopol meeting (Ubaldi, 2013), OGD began to be adopted in the 2010s across many levels of the US government, although implementation at state and municipal levels was neither required, nor constrained, by broad standards or policies (Dawes, Vidiasova \& Parkhimovich, 2016). OGD initiatives, including the data.gov portal for federal agencies were supported by administrations across party lines, suggesting that open data could become an administrative norm, rather than a political stance. Trends in the federal government after the 2016 election, however, indicate a shift away from open data and pro-active transparency. Obama's White House data portal ${ }^{1}$ provided open data collected at the White House, such as datasets on staff salaries and budget, as well as showcasing President Obama's commitment to open government by providing information on US open government initiatives and policies. After the transition to the Trump administration, the open.whitehouse.gov url was redirected to whitehouse.gov/disclosures, which offers limited data in closed formats, such as PDF versions of salary data and ethics waivers, and a contact form to request financial disclosures. In another example, data on climate change was removed from the Environmental Protection Agency websites and has yet to be replaced (Mooney and Eilperin, 2017). While the Trump administration did create a fourth Open Government Partnership action plan in February 2019, it missed two deadlines in this process, placing them under review from the OGP (Pradhan, 2019). The fourth plan is shorter and less detailed than previous plans (Open Government Partnership, 2019). Congress seems to have taken over the leading role in US OGD from the executive branch, demonstrating their commitment by requiring federal agencies to publish on data.gov as part of the OPEN Government Data Act (Kim, 2019).

These developments at the federal level motivated our interest in examining OGD initiatives at the state level, where we might expect to see some impact of a change in federal administration. The sudden loss of access to some federal data also lead us to consider the public value and long term viability of state level open data portals, which may serve as secondary sites of data sharing. In the US federalist system, states have responsibility for many important government functions, from real estate to education. Therefore, data shared through state level portals could be unique and valuable, particularly in smaller, rural states that are not anchored by large metropolitan areas served by municipal open data services. The US federal government does not require states or municipalities to adopt open data programs or adhere to any particular standards or practices. Instead each entity is encouraged to adopt and devise an OGD program suited to its own environment. Similarly, state

1 Archived at open.obamawhitehouse.archives.gov 
governments leave municipalities free to adopt their own local programmes (Dawes et al., 2016). This context allows for a great deal of variation in OGD initiatives and yet very little is known about the different forms and functions of state level portals. The vast majority of research on OGD in the United States to date has focused on the municipal and federal levels, with state level portals largely ignored.

In consideration of the importance of state level OGD initiatives and the lack of current research in this area, this study offers an initial exploration of state level data portals, with the aim of identifying the forms, features and trajectories such portals have taken over time. We adopt a public value perspective and assess the extent to which such portals are designed and equipped to offer value to members of the public.

\section{Literature Review}

There is a substantial body of literature on open government and open data initiatives; however, the majority is focused at the national and municipal level. We found very few studies of US state level open data portals. Therefore, this review draws upon the broader literature to identify goals, challenges and research findings related to OGD, as well as presenting some frameworks for evaluation that are relevant to this project.

Claims have been made that governments benefit from open data, as it allows processes to function more efficiently and transparently, potentially exposing or preventing corruption and increasing legitimacy in the eyes of citizens (Attard et al., 2015; Ubaldi, 2013). In addition to social benefits such as transparency, proponents argue that open data can provide economic benefits to governments by encouraging innovation, as well as operational benefits by optimizing government processes (Janssen, Charalabidis \& Zuiderwijk, 2012). The motivations of governments to open their data, however, are more complex than simply viewing open data as a public good. For example, increasing access to data may be a strategic move to appear open while pursuing a neoliberal agenda of privatis,ation (Bates, 2014; Sieber \& Johnson, 2015).

According to De Blasio and Selva's (2016) comparison of European open data policy documents, there are two main models of open data policy: innovation-based policies, focusing on transparency and public-private collaboration, and economic models that anchor open data initiatives within previously existing economic policies. A third, democratic policy approach involving collaborative projects with community stakeholders, is also emerging, possibly leading to a third, more participatory model. Policies may also differ based on whether the stakeholders are originally coming from a freedom of information or an information technology background, as these communities have different emphases (Lassinantti, Stahlbrost \& Runardotter, 2019). Open data portals can also be designed around models of democratic activity, with different portal designs required to support monitorial, deliberative, and/or participatory democracy (Ruijer, Grimmelikhuijsen \& Meijer, 2017). Without policies that make clear what should be published, it is difficult for OGD to serve a monitorial purpose of showing what entities are not living up to their disclosure obligations (Lourenco, 2015). 
Governments transitioning to an open data orientation face many challenges (Janssen et al., 2012). Yang, Lo and Shiang (2015) identified legal and policy frameworks as key. Difficulties navigating privacy regulations and ensuring appropriate licensing, discourage governments from opening their data. The resources required to convert data from closed formats, such as PDF, into machine-readable formats also can prevent important data from being published. Pressure from authority, organisational norms of information sharing and concerns of liability for data misuse also work to discourage the opening of data (Yang \& Wu, 2016). In local initiatives, it may be more difficult to ensure that data is anonymized and can legally be released (Conradie \& Choenni, 2014). Smaller governments may encounter additional difficulties due to a lack of resources and few locals with data expertise. Adequate resources and support are crucial for proactive data opening to be effective (Yang $\& \mathrm{Wu}, 2016)$. In a study of 10 US city data portals, population was found to be the most significant predictor of portal quality and number of datasets shared, suggesting that there is a critical mass needed to support such initiatives (Thorsby, Stowers, Wolslegel, \& Tumbuan, 2017). One strategy employed to address this issue is to create regional cooperatives to share costs and expertise with neighbouring governments (Lassinantti, Bergvall-Kareborn \& Stahlbrost, 2014). These cooperatives currently exist primarily between municipalities, counties and organisations, such as the Western Pennsylvania Regional Data Center (www.wprdc.org), but the same model could be applied to statelevel portals.

At the publishing stage, some research suggests the value of incorporating multiple types of business models into an open data project, rather than simply putting raw data into a portal (Janssen \& Zuiderwijk, 2014). Applications, aggregators, and service platforms can allow the data to be more accessible to users without high levels of comfort with technology. Different business models can also encourage different types of participation and dialogue. Although it may initially be simpler to release information such as financial data that is already in tabular form, it provides additional value to citizens to publish textual data such as meeting transcripts, and to extract, analyse and visualise the data (Steinbauer, Hiesmair, \& Anderst-Kotsis, 2016). This allows citizens to see trends in government deliberation, which will encourage them to access the primary source data rather than relying solely on summary reports from infomediaries, such as journalists.

Public support and awareness may be the key to success for an OGD initiative (Safarov, 2018). Even when a government has embraced open data, it is often difficult to engage potential users. Zuiderwijk, Janssen, \& Dwivedi (2015) found that the belief that open data would contribute to job success and data use by respected peers and colleagues, were the most significant predictors of the intent to use open data. Perceptions that data are difficult to use lessened intent. Other work has shown that data literacy is a major obstacle (Chan, Johnson \& Shookner, 2016). Interpreting a dataset can be challenging in cases where sufficient contextual metadata is not provided (Reddick et al., 2017).

Engagement with the public can also be improved by opening up datasets that are most interesting to the target groups of citizens (Both, 2012). Since many users may not know enough about available data to make informed requests, civic organisations that work with the public could play a role advocating for data they identify as useful to their constituents (Ubaldi, 2013). Co-creation can allow a variety of stakeholders to work on a shared problem using open data and capitalising on their 
different areas of expertise (McBride, Aavik, Toots, Kalvet, \& Krimmer, 2019). Balancing the needs of citizens with the goals of the government agencies opening their data may require a participatory design approach to creating the portal, to ensure that all stakeholders have a real chance to influence the design process (Maruyama, Douglas \& Robertson 2013; Sieber \& Johnson, 2015).). Continual attention to engagement is necessary, as once a portal is established, there is no guarantee it will continue to grow and flourish, but may instead be defunded or abandoned (Sieber \& Johnson, 2015).

The evaluation of open data adoption is frequently done using benchmarks (Mergel, Kleibrink \& Sorvik, 2018). Susha, Zuiderwijk, Janssen and Gronlund (2015) compared the open data benchmarks proposed by several organizations, and found that benchmarks designed to measure open data based on one type of outcome, such as implementation, are not necessarily adequate to measure other aspects, such as impact. Benchmarks should reflect a genuine understanding of the types of democratic activity the portal intends to support and therefore what aspects should be measured. Susha et al. (2015) suggest using the Open Data Barometer developed by the World Wide Web Foundation, as it is the most comprehensive and helps guide implementation toward desired impact.

Based on the literature review, we identified a number of guiding questions to focus our exploratory study of state level portals. These reflect the themes and methods of assessment prevalent in related literature and arise from a public value perspective, which considers the extent to which these portals serve as effective and sustainable services to citizens.

- What are the stated motivations and goals for the portals? How are these reflected in their design and operations?

- In what policy and resource contexts do these portals function? What, if any, challenges arise from these factors?

- To what extent are the portals designed for public engagement? Is the design user-centred and accessible to a broad range of users? Are the portals promoted and actively used?

- How do these portals develop over time? What, if any, impact do changes of administration have?

\section{Methods}

This study employs an exploratory, multiple-case study design (Yin, 1994), with the state open data portal, broadly defined, serving as the unit of study. Case studies are frequently used in OGD research (e.g. Dawes et al., 2016; McBride et al., 2019; Safarov, 2018), as they allow for a holistic perspective. In response to the research questions, the case study was designed to compare and contrast the forms and trajectories taken by several state level data portals, from their inception. We selected similar cases with limited regional and demographic variation, so as to better understand the local and political factors sharing these initiatives and their underlying similarities (Yin, 1994). Further, we reasoned that the importance of state level portals is likely to be greater in states lacking large urban centres served by municipal data portals. These considerations led us to select three New England states, Vermont, Maine, and New Hampshire. The history and present condition of these states are similar, making it meaningful to draw comparisons between them. They are among the least populous and most rural states in the US. Maine and New Hampshire are similar in population size, with 1.3 million residents each, while Vermont is smaller, with just over .6 million 
(https://www.census.gov). These states are considerably less diverse than the country as a whole, with a white population of over $90 \%$. The lack of a clear partisan stance makes these states interesting cases in the context of the 2016 change in federal administration. At the time this research was conducted (2017), all three states had Republican governors, despite having voted for the most recent Democratic presidential candidate, and Maine and Vermont were the only states represented by Independent senators.

Cases were scoped as follows: The Maine open data portal, data.maine.gov, was considered together with a second portal focused on financial data, opencheckbook.maine.gov. We treat this as a dual portal because of the prominence of Maine Open Checkbook on the primary data.maine.gov site$^{2}$. New Hampshire does not use a portal format, but maintains a web page with a list of links to open data on various government department websites. Vermont has a single, full-featured portal. Fully separate geographic map and data portals, which exist in Maine and Vermont have not been included in the analysis.

Data collection was carried out in 2017 through a mixed-methods approach, combining document analysis and content analysis (Krippendorf, 1980). We performed several content analyses as a part of this research. First, themes in the introductory and explanatory information provided by the portals were identified and categorised to look for patterns in stated goals. Units of analysis in this section were syntactical, focusing on words that occur within a dictionary of terms developed as part of the study and based on themes identified in the literature review. These included economic accountability, citizen innovation and transparency. Next, the datasets available via the portals were analysed based on content type, format, publication date, and licensing information. We framed this analysis using the dataset checklist section of the Open Data Barometer (ODB) Research Handbook to increase replicability, adapting it for application at the state, rather than national, level. We limited our analysis to 9 of the 15 types of data in in the ODB to focus on those categories of data that existed in some form on one of the portals, following an initial exploration of the data. Results were compared against benchmarks available from the ODB based on inventories of data openness, reusability, and currency (Open Data Barometer Global Report 4th ed., 2017).

We checked for evidence of data use and reuse on the portals and considered any patterns in the content of datasets that were the focus of user activity. Document analysis was used to identify changes in archived versions of the portals over time (Olsen, 2012). Any differences between previous versions of the portals and their current state were noted and compared. Finally, we examined the policies governing these portals. To guide this investigation, we used the Open Data Policy Framework (Zuiderwijk \& Janssen, 2014). The framework allows for comparison of the context and content of different policies, as well as their performance indicators.

2 Not included in this analysis is an earlier data catalogue called Maine DataShare, which went online in 2009 as part of the state e-government portal. An inactive version still exists online, containing a small number of datasets from the period 2009-2013. See, www.nascio.org/portals/0/awards/nominations2010/2010/2010ME9-NASCIO_2010_ME_DataShare.pdf 


\section{Results}

Results of the multiple case study analysis are presented in this section, beginning with an overview of the three portals and proceeding to more detailed analyses of the portal implementations and changes over time.

\subsection{Overview}

All three portals were established in 2014-2015, the period following President Obama's 2013 order making federal data open by default (Obama, 2013). Despite being developed in the same period, their implementation is varied.

The Vermont portal (https:/ / data.vermont.gov/) is most consistent with the strategy taken at the federal level, with all data (158 datasets) presented through a single portal hosted on the widelyused Socrata platform3 (Figure 1). Over the period between the launch in 2014 and our study in 2017, 44 datasets were added, indicating that it was being maintained and updated. The Vermont portal is the responsibility of the Department of Information and Innovation.

Figure 1: Front page of the Vermont Open Data Portal, July 2017

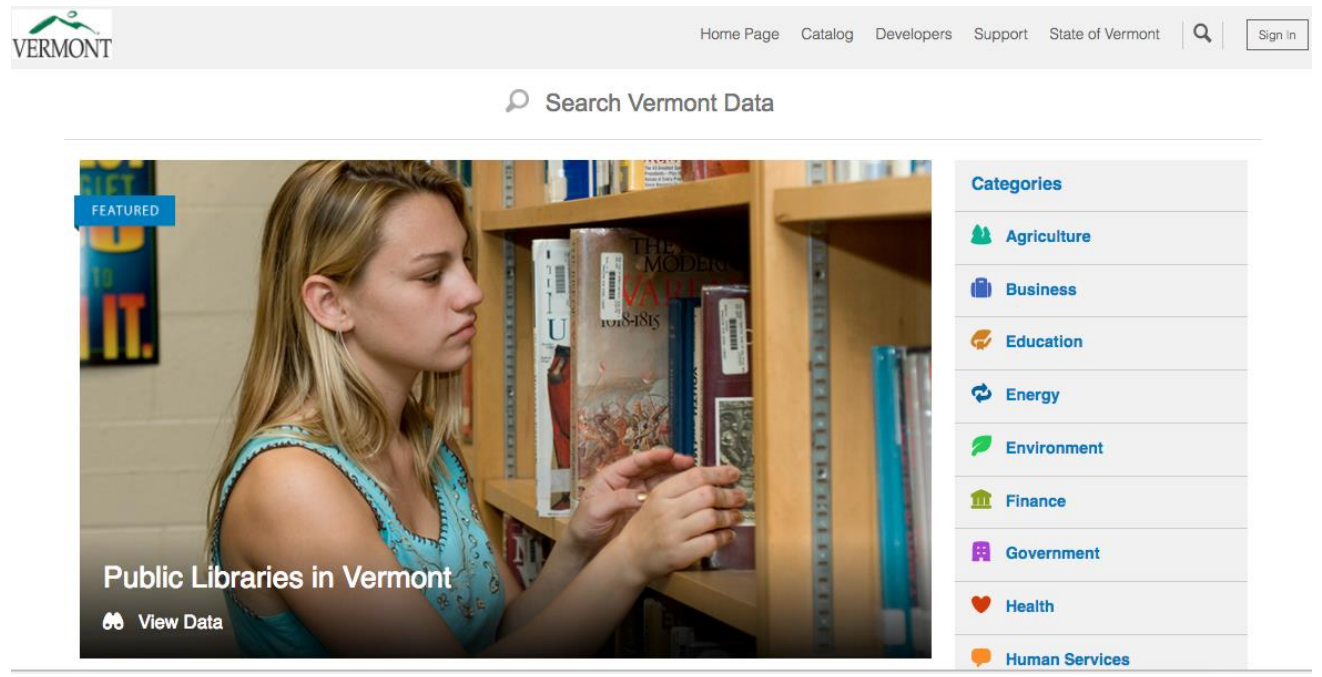

The Maine data portal (data.maine.gov) also used Socrata at the time of this study (Figure 2). However, financial data, including vendor expenses and government salary data, is hosted separately on the Open Checkbook site (opencheckbook.maine.gov), resulting in a dual portal approach. The primary portal provided access to 38 datasets, of which 18 were available from the outset and 20 were added between 2014 and 2017.

${ }^{3} \mathrm{~A}$ recent study of municipal portals found that more than $61 \%$ used the commercial Socrata platform

(Thorsby et al., 2017) 
Figure 2: Front page of Maine open data portal, July 2017
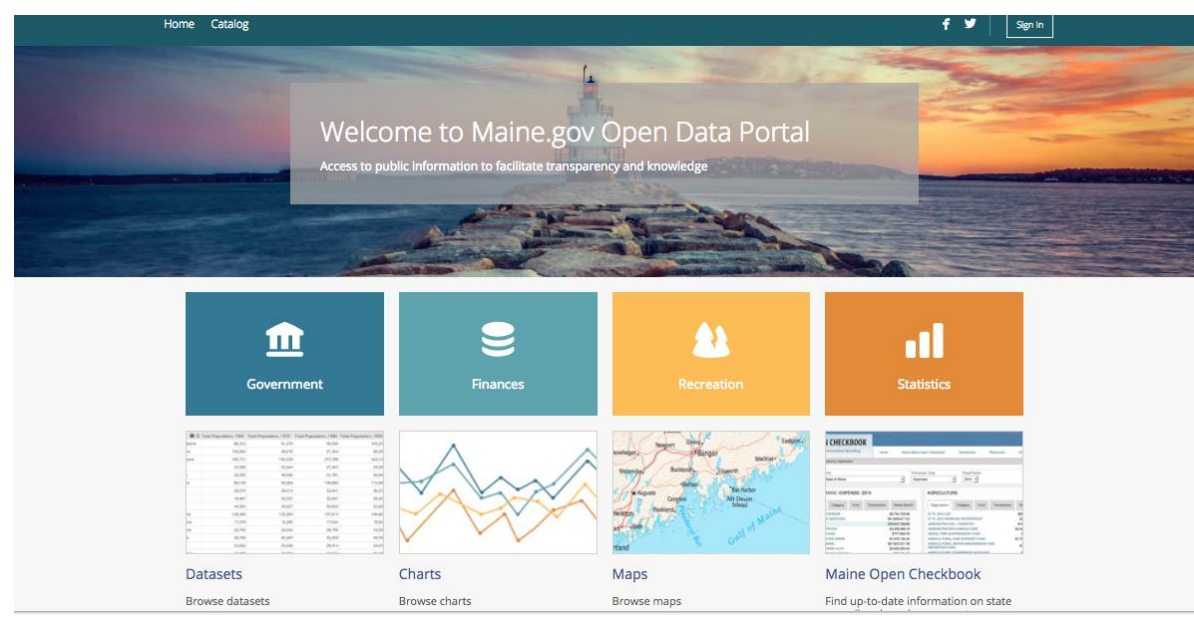

In New Hampshire, open data is provided in a simpler format. Rather than a portal that stores and provides access to datasets, it is a set of links on the Department of Information Technology website to 117 datasets hosted by different government departments 4 . The site seems to have been

established in 2015, based on the copyright notice on the website, and remained quite static from 2015 to 2017, with one dataset removed and none added.

${ }^{4}$ https://www.nh.gov/doit/open-source/data-sets.htm. 
Figure 3: New Hampshire open data web page, July 2017

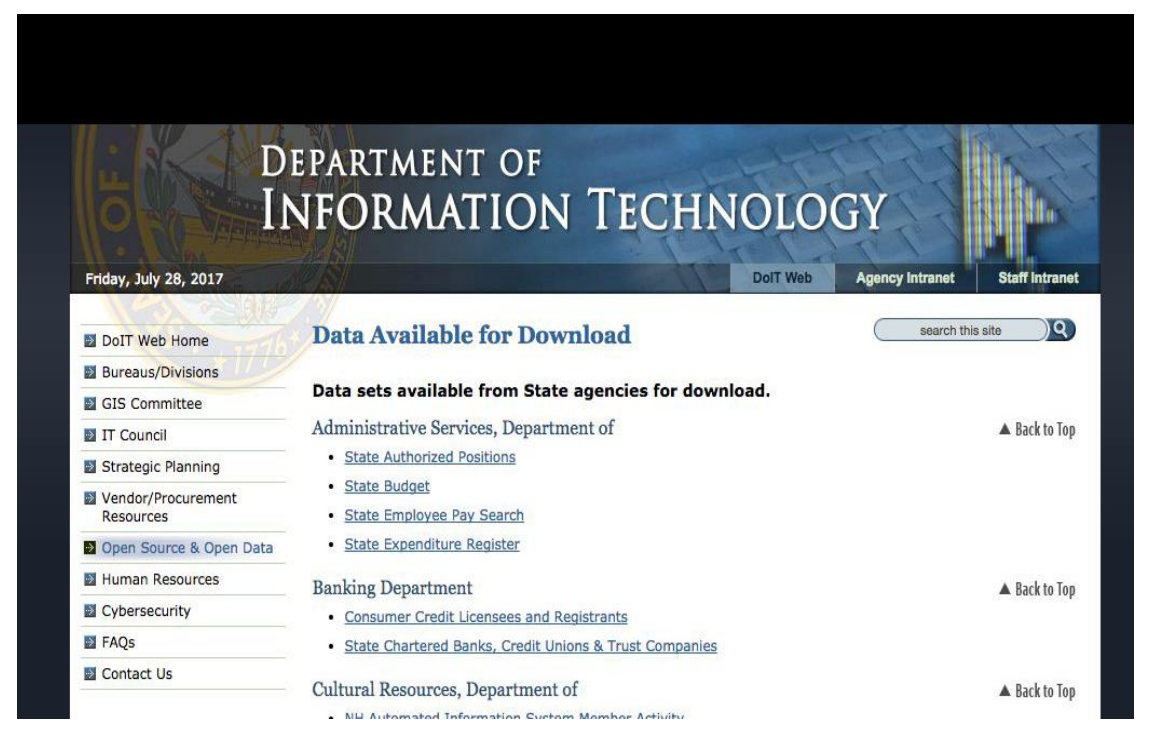

\subsection{Comparative Analysis}

A summary of the comparative analysis of the three portals is presented in Table 1, grouped into three sections: Policy and Principles, Data Characteristics, and User-Centered Features. These results are presented and discussed in more detail in the corresponding sections below.

Table 1: Summary of comparative analysis of state portals

\begin{tabular}{|c|c|c|c|}
\hline & Maine & New Hampshire & Vermont \\
\hline \multicolumn{4}{|l|}{ Policy and Principles } \\
\hline Launch Date & $\begin{array}{l}2014 \text { (replaced site } \\
\text { from 2009) }\end{array}$ & $\begin{array}{l}2015 \text { (Copyright } \\
\text { date) }\end{array}$ & 2014 \\
\hline $\begin{array}{l}\text { Primary motivations } \\
\text { for sharing data }\end{array}$ & $\begin{array}{l}\text { Transparency, } \\
\text { Economics, } \\
\text { Participation, } \\
\text { Education }\end{array}$ & $\begin{array}{l}\text { Transparency, } \\
\text { Economics }\end{array}$ & Participation, Education \\
\hline $\begin{array}{l}\text { Policy Measures and } \\
\text { Instruments } \\
\text { referenced }\end{array}$ & None & $\begin{array}{l}\text { Regulation } \\
\text { (RSA 21-R:10-13) }\end{array}$ & None \\
\hline $\begin{array}{l}\text { Stated principles for } \\
\text { data } \\
\text { inclusion/exclusion }\end{array}$ & No principles stated & $\begin{array}{l}\text { Data published } \\
\text { must be in open } \\
\text { formats }\end{array}$ & $\begin{array}{l}\text { Opt-in by agency; } \\
\text { any data that is not } \\
\text { private, personal or } \\
\text { sensitive }\end{array}$ \\
\hline
\end{tabular}




\begin{tabular}{|c|c|c|c|}
\hline $\begin{array}{l}\text { Data Licenses applied } \\
\text { within the portal }\end{array}$ & $\begin{array}{l}\text { Public domain, } \\
\text { unspecified }\end{array}$ & $\begin{array}{l}\text { No license } \\
\text { information } \\
\text { available }\end{array}$ & $\begin{array}{l}\text { Open Database License, } \\
\text { Public Domain, } \\
\text { unspecified }\end{array}$ \\
\hline $\begin{array}{l}\text { Processing of data } \\
\text { before publication }\end{array}$ & No information & No information & $\begin{array}{l}\text { Check for sensitive } \\
\text { information }\end{array}$ \\
\hline \multicolumn{4}{|c|}{ Data Availability and Characteristics } \\
\hline Number of Datasets & 38 & 117 & 158 \\
\hline Data formats & $\begin{array}{l}\text { CSV, JSON, RDF, } \\
\text { RSS, TSV, XML, } \\
\text { KML, KMZ, } \\
\text { Shapefile, GeoJSON }\end{array}$ & $\begin{array}{l}\text { Open only (CSV, } \\
\text { DWG, JSON, KML, } \\
\text { SHP, XLS, XML) }\end{array}$ & $\begin{array}{l}\text { CSV, JSON, RDF, RSS, } \\
\text { TSV, XML, links to } \\
\text { external data in closed } \\
\text { formats }\end{array}$ \\
\hline Types of Open Data & $\begin{array}{l}\text { Varied- financial, } \\
\text { crime, hunting, } \\
\text { geographic, } \\
\text { population }\end{array}$ & $\begin{array}{l}\text { Varied- finance, } \\
\text { education, } \\
\text { employment } \\
\text { security, } \\
\text { environmental } \\
\text { services, strategic } \\
\text { planning }\end{array}$ & $\begin{array}{l}\text { Varied- finance, } \\
\text { government, public } \\
\text { safety, energy, } \\
\text { education, health, } \\
\text { human services }\end{array}$ \\
\hline Provision of metadata & Limited metadata & $\begin{array}{l}\text { No metadata } \\
\text { provided, some } \\
\text { individual } \\
\text { departments } \\
\text { provide }\end{array}$ & Limited metadata \\
\hline \multicolumn{4}{|l|}{ User-centered Features } \\
\hline $\begin{array}{l}\text { Availability of tools } \\
\text { for analysis }\end{array}$ & Filter and visualise & None provided & Filter and visualise \\
\hline Technical support & No information & No information & $\begin{array}{l}\text { Training available- } \\
\text { unclear if open to } \\
\text { general public }\end{array}$ \\
\hline $\begin{array}{l}\text { Communication } \\
\text { between information } \\
\text { suppliers and users }\end{array}$ & $\begin{array}{l}\text { Users can contact } \\
\text { data providers } \\
\text { through the platform }\end{array}$ & $\begin{array}{l}\text { No in-portal contact } \\
\text { options }\end{array}$ & $\begin{array}{l}\text { Users can contact data } \\
\text { providers through the } \\
\text { platform }\end{array}$ \\
\hline Evidence of data use & $\begin{array}{l}3 \text { community users, } \\
\text { no apps recorded }\end{array}$ & No usage recorded & $\begin{array}{l}14 \text { community users, no } \\
\text { apps recorded }\end{array}$ \\
\hline
\end{tabular}




\subsection{Policy and Principles}

Of the three states, only New Hampshire has laws specifically relating to open data. RSA 21-R:10-13 (2012) requires that all data published by the government use open standards unless a specific project requirement or high cost makes this untenable. The effectiveness of this law is evident, since all datasets shared in the portal are in open formats. However, this legislation does not require that all data be published online. While New Hampshire's Right to Know laws guarantee access to most government records and electronic communications, proactive release is not required (Right to know law, 2017). Vermont does not have legislation in place to support open data or proactive data release beyond the state's Public Records law. "An Act relating to creating an Office of Public Policy," was considered by the legislature in 2015 but remained stuck in committee (An act relating to the creating of an Office of Public Policy, H. 435, 2015). The bill aimed to establish Vermont as "an open data democracy state whereby the Office shall redact any personal identifying information from data the State collects and shall organize and share the State's data with the public online in a manner that enables the public to perform analyses with that data". If passed, such legislation would establish a strong legal basis for an open data programme. Maine does not have open data legislation in place, nor does it seem to have initiated any dialog around open data laws thus far. In fact, in 2013 three bills proposed in the state legislature sought to exempt additional record types from basic Freedom of Access requests (Misteler, 2013).

Based on the content analysis of informational text on the portals, transparency is the most commonly referenced aim for providing open data, followed by education, fiscal responsibility, and public participation (Table 1). For example, the Maine portal displays a commitment to "transparency and knowledge" on its landing page, reflecting the broader goals of the open data movement. There are slight variations in emphasis, with Maine and New Hampshire citing economic goals of fiscal responsibility and economic stimulus, and Vermont focusing more on education and public participation. Maine, which has the broadest goals, offers both the Open Checkbook site, emphasising fiscal responsibility, and the Socrata portal designed for public engagement.

Responsibility for the portals seems to rest with the state information technology offices. The New Hampshire Department of Information Technology hosts the open datasets page, but it is not apparent where the authority stands on deciding which datasets to include. The Vermont Department of Information and Innovation oversees data.vermont.gov, with other government departments able to request accounts to add datasets. In the case of Maine, the Open Checkbook portal states that it is operated and funded by the Office of the State Controller's transparency programme and provides contact information for the portal staff. In contrast, data.maine.gov provides no information about who is responsible for the portal; however, the contact email goes to InforME, the office in charge of Maine's websites and e-government services. The email address was not responsive at the time of the study.

The portals offer very little information on policies and processes for selecting and preparing the data for inclusion (Table 1). The Vermont portal contains only the instruction that any data added by an outside department must be checked thoroughly for personally identifying information. There 
is no information on data selection or preparation in the Maine or New Hampshire portal. Further, none of the portals publish any sort of updating schedule, so this information can only be gleaned from past practices. New Hampshire leaves responsibility for keeping data up to date with the departments. As a result, the most recent version of a dataset may have been updated days ago or over a decade ago, depending on the priorities of the department. Maine does not provide any information on updating and many of the datasets were not updated since being added to the portal. Updating is most consistent in the Vermont portal, but it is difficult to determine whether this follows a set schedule, or occurs at the discretion of the dataset owners or portal managers.

\subsection{Data Availability and Characteristics}

Table 2 provides a summary of our analysis of the datasets provided in each of the portals, based on standard data types and characteristics used in the ODB project. Examination of the types of data represented within the portals reveals some patterns. Census data is the only type provided by all states, and is the first - or second - most frequent category of datasets across the three portals. This data, already readily available from federal census and statistics sources, is an important resource to provide locally, as it enables comparison of other datasets to population statistics. All other types are only offered by one or two of the portals, indicating a low level of consistency in offerings. Maine and Vermont offer some map/geospatial data, although both states have separate dedicated GIS portals. As with census data, map data is important in support of data use, enabling users to overlay other datasets onto state maps. Maine and Vermont both provide access to crime data, and notably, these states have the lowest crime rates in the nation (Violent crime rate by state, 2017). Maine and New Hampshire both publish data on government spending on their data portals, notwithstanding the additional financial data on Maine's Open Checkbook application, in keeping with their stated aims to promote fiscal responsibility and economic benefit through open data. Additionally, there were some categories of data that only one of the selected portals published, such as New Hampshire's education performance data and Vermont's public contracts and health sector performance data.

Several categories of data included in the ODB were not provided by any portal. Some of these, such as international trade and public transit data, are not particularly relevant to small, rural states. Other types, such as land ownership data, company registers and election results were not included on these portals, perhaps because they are readily available elsewhere. All of the portals contained types of data not covered by the ODB project. Some of these seem to reflect the unique context of the state and/or the stated goals for the portal. Maine included datasets about hunting and wildlife management in keeping with its reputation as a hub for outdoor sports, as well as information about veteran's services, perhaps in response to the high percentage of Maine residents who are veterans (Chokshi, 2014). New Hampshire's additional datasets focus on business and economic interests, presenting bank charters, employment projections, and elevator inspections, as well as datasets that could prove useful to citizens such as traffic data, the location of polling places, and data on native plants. Vermont's portal offers the largest number of datasets of the three, and thus has the greatest variety as well. One example is licensing information for tradespersons and child care providers. Other popular datasets show the locations of community resources, such as libraries and retailers 
who accept Supplemental Nutrition Assistance Program (SNAP) payments. These Vermont datasets are frequently viewed and updated, indicating that they are useful to the community.

Table 2: Data availability comparison by state, based on ODB checklist (www.opendatabarometer.org)

\begin{tabular}{|c|c|c|c|c|c|c|c|c|c|}
\hline & $\begin{array}{l}\frac{\pi}{\pi} \\
0 \\
\tilde{0} \\
\sum\end{array}$ & 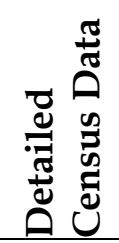 & $\begin{array}{l}\bar{d} \\
00 \\
0 \\
0 \\
0 \\
0 \\
0 \\
0\end{array}$ & 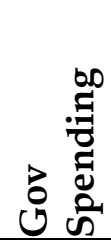 & 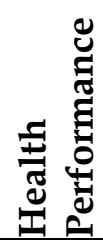 & 预 & 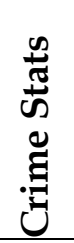 & 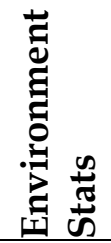 & 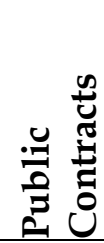 \\
\hline Data available? & $\begin{array}{l}\text { ME } \\
\text { VT }\end{array}$ & $\begin{array}{l}\mathrm{ME} \\
\mathrm{NH} \\
\mathrm{VT} \\
\end{array}$ & $\begin{array}{l}\text { NH } \\
\text { VT }\end{array}$ & $\begin{array}{l}\mathrm{ME} \\
\mathrm{NH}\end{array}$ & VT & $\mathrm{NH}$ & $\begin{array}{l}\mathrm{ME} \\
\mathrm{VT} \\
\end{array}$ & $\begin{array}{l}\mathrm{NH} \\
\mathrm{VT}\end{array}$ & $\mathrm{VT}$ \\
\hline $\begin{array}{l}\text { Machine readable and reusable } \\
\text { format? }\end{array}$ & $\begin{array}{l}\text { ME } \\
\text { VT }\end{array}$ & $\begin{array}{l}\mathrm{ME} \\
\mathrm{NH} \\
\mathrm{VT} \\
\end{array}$ & $\begin{array}{l}\mathrm{NH} \\
\mathrm{VT}\end{array}$ & $\begin{array}{l}\mathrm{ME} \\
\mathrm{NH}\end{array}$ & VT & $\mathrm{NH}$ & $\begin{array}{l}\mathrm{ME} \\
\mathrm{VT} \\
\end{array}$ & $\begin{array}{l}\mathrm{NH} \\
\mathrm{VT}\end{array}$ & VT \\
\hline $\begin{array}{l}\text { Machine readable, reusable } \\
\text { and available as a whole? }\end{array}$ & $\begin{array}{l}\text { ME } \\
\text { VT }\end{array}$ & $\begin{array}{l}\mathrm{ME} \\
\mathrm{NH} \\
\mathrm{VT}\end{array}$ & $\begin{array}{l}\text { NH } \\
\text { VT }\end{array}$ & $\begin{array}{l}\mathrm{ME} \\
\mathrm{NH}\end{array}$ & VT & $\mathrm{NH}$ & $\begin{array}{l}\mathrm{ME} \\
\mathrm{VT}\end{array}$ & $\begin{array}{l}\mathrm{NH} \\
\mathrm{VT}\end{array}$ & VT \\
\hline Free of charge? & $\begin{array}{l}\text { ME } \\
\text { VT }\end{array}$ & $\begin{array}{l}\text { ME } \\
\mathrm{NH} \\
\mathrm{VT}\end{array}$ & $\begin{array}{l}\mathrm{NH} \\
\mathrm{VT}\end{array}$ & $\begin{array}{l}\mathrm{ME} \\
\mathrm{NH}\end{array}$ & VT & $\mathrm{NH}$ & $\begin{array}{l}\text { ME } \\
\text { VT }\end{array}$ & $\begin{array}{l}\mathrm{NH} \\
\mathrm{VT}\end{array}$ & VT \\
\hline $\begin{array}{l}\text { Openly } \\
\text { licensed? }\end{array}$ & $\mathrm{ME}$ & $\begin{array}{l}\text { ME } \\
\text { VT } \\
\end{array}$ & & ME & & & $\begin{array}{l}\mathrm{ME} \\
\mathrm{VT} \\
\end{array}$ & VT & $\mathrm{VT}$ \\
\hline Up to date? & $\begin{array}{l}\text { ME } \\
\text { VT }\end{array}$ & $\mathrm{NH}$ & $\mathrm{NH}$ & $\mathrm{NH}$ & VT & $\mathrm{NH}$ & VT & $\mathrm{NH}$ & VT \\
\hline Regularly updated? & $\begin{array}{l}\text { ME } \\
\text { VT }\end{array}$ & $\mathrm{NH}$ & $\mathrm{NH}$ & $\mathrm{NH}$ & & & VT & $\mathrm{NH}$ & VT \\
\hline $\begin{array}{l}\text { Easy to find information about } \\
\text { dataset? }\end{array}$ & VT & & & ME & VT & $\mathrm{NH}$ & $\begin{array}{l}\mathrm{ME} \\
\mathrm{VT}\end{array}$ & VT & VT \\
\hline $\begin{array}{l}\text { Data identifiers for key } \\
\text { elements? }\end{array}$ & $\begin{array}{l}\text { ME } \\
\text { VT }\end{array}$ & $\begin{array}{l}\mathrm{ME} \\
\mathrm{NH} \\
\mathrm{VT} \\
\end{array}$ & $\begin{array}{l}\mathrm{NH} \\
\text { VT }\end{array}$ & $\begin{array}{l}\mathrm{ME} \\
\mathrm{NH}\end{array}$ & VT & $\mathrm{NH}$ & $\begin{array}{l}\mathrm{ME} \\
\mathrm{VT}\end{array}$ & $\begin{array}{l}\mathrm{NH} \\
\mathrm{VT}\end{array}$ & $\mathrm{VT}$ \\
\hline
\end{tabular}

Table 2 indicates some patterns in terms of data characteristics. In most cases, if a dataset is available, it is in an open format, complete, free of charge, and contains basic descriptive information. There is much less consistency with respect to licensing, currency, and information about updating. The lack of consistent open licensing is particularly important, as this is an essential component of open data re-use (Ubaldi, 2013). New Hampshire's portal does not provide licensing information on the main page, and licensing information is inconsistently included with the datasets themselves. The Socrata platform provides a space for licensing information, but both Maine and Vermont leave this unspecified for many of the datasets. For those datasets that do specify license, many are licensed Public Domain, and others use the Open Database license. 
The availability of more detailed information about datasets (metadata and links to source materials) also varied. On the Maine and Vermont portals, the Socrata interface automatically generates some metadata, such as the date the portal was last updated, but metadata such as tags and keywords were seldom added by the dataset uploader. New Hampshire does not provide any metadata within the portal beyond title. The individual datasets sometimes include useful metadata, depending on the department.

\subsection{User-Centred Features and Portal Use}

The front pages of the portals show varying approaches to presenting the data. Although New Hampshire does not have such a landing page before its data catalog, Vermont and Maine both have datasets highlighted visually at their main URL before presenting the full data catalog. Maine focuses on content areas (Government, Finance, Recreation and Statistics) and content types (Datasets, Charts, Maps and Open Checkbook). Vermont features individual datasets, with a menu of categories to the right, and tags and categories are included for nearly every dataset, offering users several pathways to find data. The method of organising information used in the Maine portal is less flexible and relies on users having prior knowledge of available data. The application of categories and tags is inconsistent, which, combined with the choice to split data provision across two portals, makes data discovery more difficult. New Hampshire's page lacks the added value of data visualisation tools. Datasets are listed by government department, which is known to be less effective than user-centred approaches that employ broad subject categories or the life events approach (Vintar, Kunstelj \& Leben, 2002). There are no keywords, subject categories, or search tools included in this portal, which means that data discovery is reliant on browsing or prior knowledge of what data is produced by each department. Of the portal design choices, Vermont's comes closest to following best practices for user-centred design.

It is difficult to determine the extent of use of these portals. The New Hampshire portal does not provide any usage information, so there is no way to determine how frequently it is accessed. A Google search for the website URL returns only a handful of pages that link to the portal page, indicating that it is not widely referenced and relatively unfindable. In contrast, the Maine and Vermont portals are more widely referenced, including links from directories of open data portals and from sites referencing specific datasets, suggesting use by different organisations and companies. For these Socrata-based portals, metrics on dataset views and downloads provides further information into use. At the time of the study, Vermont's most viewed item, a filtered view of fuel prices, was accessed 10,918 times and downloaded 82 times. Maine's most viewed item, a map of Maine lighthouses, was accessed 7,555 times and downloaded 59 times. Vermont had 14 contributing users who created 18 filtered views, charts, or maps. Maine had three community users who had created six information products. Neither portal offers interactive features such as message boards or commenting options that could provide evidence of an engaged user community.

Additional factors inhibit the portal's potential for re-use. It is difficult for users to determine what, if any, technical support is provided. It is possible that state information technology help desks, such as InforME and the Department of Information and Innovation, would provide some technical support, but it is unclear whether their services extend to public use. The Socrata platform 
does provide some tutorials to support users in the basics of working with data, but the link to these tutorials is not featured prominently on either the Maine or Vermont portals, and is instead hidden in the filters tab of the dataset viewer. New Hampshire does not provide any apparent user support and the only contact is the webmaster of the site. Common to all three portals is a lack of advertising and communication. It is difficult to discover these portals via other government websites due to inadequate linking and they have no social media presence, so most traffic would have to come from search engine users seeking open data. Common strategies for promoting open data, such as hackathons or application creation contests (Ubaldi, 2013), do not seem to have been tried in relation to these portals. As a result, user interaction has been minimal, with no recorded instances of the data being re-used to make applications or projects.

\subsection{History and Change}

We examined the development of these portals over the period between their establishment and the study collection in 2017 through evidence of additions and changes in datasets and the snapshots available from the Internet Archive. Each of the portals has followed a different trajectory of change through time, with no clear evidence that changes in the federal administration in 2016 had an impact on these state level initiatives. The New Hampshire page, established sometime in 2015, has remained fundamentally unchanged, despite the shift from Democratic to Republican state leadership in 2016. Comparing the 2017 version with the single snapshot from the Internet Archive indicates that one dataset was removed and none added through this period. At our latest check in June 2019, the page remains fundamentally the same, with 117 datasets still listed. The Maine portal was established late in 2014 and saw an initial flurry of activity in 2015 and 2016 followed by a slow trickle of additions to the portal, a period of stasis and eventual obsolescence. When we carried out the study in 2017, the portal was still live, but offering the same 38 items that were available in 2016. Given the timing of the decline in activity, it is possible that the political will behind the portal initiative diminished in the face of the Trump administration; however, our data is too limited to draw such a conclusion. A Republican governor was in office in Maine throughout this entire period. Our latest check-in showed that the site has been decommissioned, likely early in 2019. In contrast, the Maine Open Checkbook application, administered by Office of the State Controller, is still available and up-to-date. Vermont's portal was established in 2014, and has grown slowly and steadily since that time. At the time of this study, it had 143 items in its catalogue, and as of our latest check in 2019, it has over 200. While functional and active, it is worth noting that the "featured" datasets on the portal have not been updated since it was established. One significant change is the 2016 removal of a link to a "Governor's Dashboard" that had been an initiative of the Democratic Governor Peter Shumlin. The dashboard, available via the Internet Archive, shared summaries, charts and datasets on a range of topics, such as jobs and infrastructure, and operated separately from the Vermont open data portal. The dashboard was discontinued when Republican GovernorPhil Scott gained office in the 2016 general election, although the operations of the state data portal were not affected.

It is worth noting that OGD initiatives preceded the portals included in this study. Maine had offered an earlier portal, Maine DataShare, which had not been updated for several years when it was superseded by the Socrata portal. Some, but not all of the data, was moved over to the new 
portal and DataShare was still lingering online in 2017. Similarly, New Hampshire had a previous data portal at nhopengovt.org, which now leads to an insurance sales site (NHOpenGovt lets you Google your government, n.d.). The data that was once available through this portal does not seem to be available elsewhere online. Overall, we observed considerable instability of these portals over time and trajectories that varied substantially across the three cases.

\section{Discussion and Conclusions}

In the northern New England states, the future of the state-level data portals is uncertain. Four to five years after the creation of these portals, Vermont continues to update and improve its portal in a minor way, the Maine portal is no longer available, and New Hampshire has made almost no updates to its original portal, although it continues to function. Vermont's model, a single portal with software that supports users' creation of visualisations, seems to be more effective for users than Maine's dual portals or New Hampshire's list site. This is interesting, in that Vermont has the smallest population of the three states, and prior research suggests that population is correlated with the quality of data portals, at least at the municipal level (Thorsby et al., 2017).

The results offer some insight into the research questions guiding the study. We observed that the goals of these initiatives were consistent with those identified in prior work and included transparency, economic motivations and public education and engagement. Differences in the primary motivations for these initiatives do seem to have some impact on the design and operations, illustrated best by the contrast between Vermont's engaging, public facing portal, offering a wide and growing range of social and community datasets and New Hampshire's minimalist and institutional approach, emphasising administrative data and remaining static over a lengthy period of time. It would be difficult to conclude that any of these portals fully satisfy the goals of openness and transparency given the limited amount of data shared and the lack of substantial promotion, uptake or use by the public. Vermont's portal comes closest, while the Maine portal seems to have functioned more as a signifier of openness and public engagement than a demonstration of genuine and sustained commitment (Harrison et al, 2012; Sieber \& Johnson, 2015).

With respect to the policy context, only New Hampshire has a legal requirement for open data, and none of the portals make reference to underlying policies, procedures or consistent licensing. A limitation in all cases is the lack of guiding policy or even clear definitions of notions such as transparency that could guide decision making and evaluation of these initiatives (Lourenco, 2015). The lack of attention to consistent open licensing is surprising, given that this is a core principle of OGD (Ubaldi, 2013). In all cases, the information and technology units seem to hold primary responsibility for the portals, with little obvious involvement from other departments. According to Lee (2013) egovernment services are most successful when interdepartmental working relationships are strong, something which seems to be missing in these cases. The limitations of our methods of data collection prevent this study from determining the extent to which concerns over licensing, data privacy or financial and human resources may have served as constraints on the development of the portals. Further research is needed in these areas. 
Results were mixed with regard to the design and use of the portals. There was no indication of use for New Hampshire's site, and while Vermont and Maine did have some user interaction, there is no evidence of the kinds of transformative uses often claimed by OGD advocates. We identified a number of common issues that limit the usefulness of these portals for the general public. One is the incomplete and inconsistent information provided, including metadata and licensing information. Effective use and discovery of datasets is limited without the context provided by sufficient documentation (Bennet \& Harvey, 2009). Further, without making the terms for re-use clear, users cannot know whether or not they have a legal right to create new products with the data (Ubaldi, 2013). The ambiguity of portal ownership is also a concern. Although all of the portals have some relationship with their state's information technology department, finding a contact person who is able to answer questions about the portal is extremely challenging. This exacerbates the lack of licensing information, as contacting the data owners becomes more complicated. In this respect, the New Hampshire approach of simply pointing to datasets held by various agencies may be most effective, as at least the source of the data is clear. Related to this issue is a lack of technical support. Portals do not provide any assistance to users having difficulty navigating the portal. The training materials the Maine and Vermont portals provide are minimal and hidden, decreasing the likelihood that they will be used.

Given the degree of variation in data provided across these portals, it is clear that data sharing decisions were not driven by generic standards, such as the Open Data Barometer, but rather by local interests and conditions. These state level portals contain eclectic collections of data, some of which are targeted to citizen needs and interests and some of which are unique and localized, that may serve tourism or other state-level goals. In the case of Vermont, the availability of data seems to be dependent upon individual departments opting in. Further research is needed to better understand the factors shaping decisions about data sharing; however, it is clear that the cases we studied do not offer definitive or comprehensive collections of data that would serve the interests of monitorial democracy (Ruijer, Grimmelikhuijsen \& Meijer, 2017).

Examining the portals over time was quite revealing, in that each took a different path over a brief but significant period of time in US politics. The Maine portal's waning trajectory illustrates that OGD initiatives may have limited lifespans if they lack support (Sieber \& Johnson, 2015), and suggests that future research into failed OGD initiatives may be informative. While we did not find clear evidence that data portals at the state level are subject to political transitions at the federal level, we can conclude that without legislative or policy frameworks for such initiatives, they are vulnerable to changes in conditions, including political will and resource availability. The removal of the Governor's Dashboard in Vermont and the decommissioning of older data portals in Maine and New Hampshire are illustrations of these sustainability issues.

These case studies provide a snapshot of some of the limitations and successes that smaller states experience in creating and maintaining open data portals. Since state portals have not been the object of as much research attention as national or municipal portals, this work represents a first step. The datasets currently available, in their existing form, are inadequate to support the innovation and optimized government processes that are promoted by open data advocates (Janssen et al., 2012). 
While the portals express intentions to create transparency, in practice they do not provide the necessary support to offer substantial public value.

There are several limitations of this study. The case studies were focused on the portals themselves and associated information on the public Web. We did not gather insider perspectives through interviews or non-public documents, and such information would have enabled us to reach a deeper understanding of the constraints and processes involved. The difficulty of making contact with those responsible for these data initiatives was an obstacle and highlights the lack of a usercentred or participatory orientation. A further limitation is that due to the nature of case studies, these results cannot be generalised. Even among these three New England states, there are substantial differences in the approaches taken, and this variety is likely to be true across open data initiatives.

Further exploration of the general usefulness of state data portals is necessary. The portals investigated in this study were not heavily used, and did not lead to the development of citizen-led or commercial applications or projects. If state data portals are generally ineffective, a new approach to sub-federal open data may need to be considered. Since perceived usefulness for work is a key motivator for open data users, OGD initiatives might focus on making the portal's data a part of users' daily workflow, starting by finding ways to use it for internal operations in government (Zuiderwijk et al., 2015). If the portal creators undertook promotion efforts, and then publicised the resulting applications or projects that used the data, it might attract more users and create a more vibrant culture of use. Partnerships across government agencies, professional groups and civil society could also be beneficial to improve the quality of the portals, ensure that users' needs are met, and encourage use. By addressing these issues, state governments may have greater success in attaining the goals that prompted the creation of these portals, and in sustaining them over time.

\section{References}

An act relating to the creating an office of public policy, H. 435. (2015). Retrieved from http:/ legislature.vermont.gov/bill/status/2016/H.435

Alonso, J. M., Ambur, O., Amuito, M. A., Anzanon, O., Bennett, D., Flagg, R., \& Sheridan, J. (2009). Improving access to government through better use of the web. Retrieved June 15, 2017, from https://www.w3.org/TR/egov-improving/

Attard, J., Orlandi, F., Scerri, S, \& Auer, S. (2015) A systematic review of open government initiatives. Government Information Quarterly, 32: 399-418.

Bates, J. (2014). The strategic importance of information policy for the contemporary neoliberal state: The case of OGD in the United Kingdom. Government Information Quarterly, 31 (3), 388-395. Retrieved from https:// doi.org/10.1016/j.giq.2014.02.009

Bennet, D., \& Harvey, A. (2009). Publishing Open Government Data. Retrieved August 15, 2019 from https://www.w3.org/TR/gov-data/

Both, W. (2012). Open data - what the citizens really want. The Journal of Community Informatics, 8 (2). Retrieved July 24, 2017, from http://ci-journal.net/index.php/ciej/article/view/814 
Chan, M., Johnson, P., \& Shookner, M. (2016). Assessing the use of government open data and the role of data infomediaries: The case of nova scotia's community counts program. JeDEM - eJournal of eDemocracy and Open Government, 8 (1), 1-27.

Chokshi, N. (2014). What each state's veteran population looks like. Retrieved July 24, 2017, from https://www.washingtonpost.com/blogs/govbeat/wp/2014/11/11/what-each-states-veteran-population-looks-like-in-10-maps/?utm_term=.365a7ac15f00

Conradie, P., \& Choenni, S. (2014). On the barriers for local government releasing open data. Government Information Quarterly, 31 . Retrieved from https://doi.org/10.1016/j.giq.2014.01.003

Dawes, S. S., Vidiasova, L., \& Parkhimovich, O. (2016). Planning and designing OGD programs: An ecosystem approach. Government Information Quarterly, 33 (1), 15-27. Retrieved from https://doi.org/10.1016/j.giq.2016.01.003

De Blasio, E., \& Selva, D. (2016). Why choose open government? motivations for the adoption of open government policies in four european countries. Policy and Internet, 8 (3). Retrieved from https://doi.org/10.1002/poi3.118

G. 8 Open Data Charter and Technical Annex - Gov. UK. (2013). Retrieved June 4, 2017, from https://www.gov.uk/government/publications/open-data-charter/g8-open-data-charter-and-technical-annex

Harrison, T. M., Guerrero, S., Burke, G. B., Cook, M., Cresswell, A., Helbig, N., .. Pardo, T. (2012). Open government and e-government: Democratic challenges from a public value perspective. Information Polity, 17(2), 83-97. https:// doi.org/10.3233/IP-2012-0269

Janssen, M., Charalabidis, Y., \& Zuiderwijk, A. (2012). Benefits, adoption barriers and myths of open data and open government. Information SystemsManagement, 29 (4), 258-268. Retrieved from https://doi.org/10.1080/10580530.2012.716740

Janssen, M., \& Zuiderwijk, A. (2014). Infomediary business models for connecting open data providers and users. Social Science Computer Review, 32 (5), 694-711. Retrieved from https://doi.org/10.1177/0894439314525902

Kim, H. (2019). Data.gov at Ten and the OPEN Government Data Act. Retrieved July 8, 2019 from https://www.data.gov/meta/data-gov-at-ten-and-the-open-government-data-act/

Krippendorf, K. (1980). Content analysis: An introduction to its methodology. Beverly Hills: Sage Publications.

Lassinantti, J., Bergvall-Kåreborn, B., \& Ståhlbröst, A. (2014). Shaping local open data initiatives: Politics and implications. Journal of Theoretical and Applied Electronic Commerce Research; Curicó, 9 (2), 17-33.

Lassinantti, J., Ståhlbröst, A., \& Runardotter, M. (2019). Relevant social groups for open data use and engagement. Government Information Quarterly, 36(1), 98-111. https://doi.org/10.1016/j.giq.2018.11.001

Lee, J. (2013). Exploring the role of knowledge networks in perceived e-government: A comparative case study of two local governments in Korea. American Review of Public Administration, 43 (1), 89-108. Retrieved from https://doi.org/101177/0275074011429716 
Lourenço, R.P. (2015) An analysis of open government portals: A perspective of transparency for accountability. Government Information Quarterly, 32:323-332.

Maruyama, M., Douglas, S., \& Robertson, S. (2013). Design teams as change agents: Diplomatic design in the open data movement. In 46th Hawaii International Conference on System Sciences. Retrieved from https://doi.org/10.1109/HICSS.2013.170

McBride, K., Aavik, G., Toots, M., Kalvet, T., \& Krimmer, R. (2019). How does open government data driven co-creation occur? Six factors and a 'perfect storm'; insights from Chicago's food inspection forecasting model. Government Information Quarterly, 36(1), 88-97. https://doi.org/10.1016/j.giq.2018.11.006

Mergel, I., Kleibrink, A., \& Sörvik, J. (2018). Open data outcomes: U.S. cities between product and process innovation. Government Information Quarterly, 35(4), 622-632.

https://doi.org/10.1016/j.giq.2018.09.004

Mistler, S. (2013, March). In maine, 'sunshine' law's fate looks dim. Portland Press Herald. Retrieved July 20, 2017, from http:/ / www.pressherald.com/2013/03/02/sunshine-laws-fate-looks-dim-in-maine_2013$03-03 /$

Mooney, C., \& Eilperin, J. (2017, April). Epa website removes climate science site from public view after two decades. Retrieved June 2, 2017, from https:/ / www.washingtonpost.com/news/energy-environment/wp/2017/04/28/epa-website-removes-climate-science-site-from-public-view-after-two-decades/

NHOpenGovt lets you Google your government. (n.d.). Retrieved July 24, 2017, from http:/ /www.jbartlett.org/nhopengov-lets-you-google-your-government

Obama, B. (2009, January). Executive order - transparency and open government. Retrieved May 20, 2017, from https:/ / obamawhitehouse.archives.gov/the-press-office/transparency-and-open-government

Obama, B. (2013, May). Executive order - making open and machine readable the new default for government information. Retrieved June 14, 2017, from https:/ / obamawhitehouse.archives.gov/the-pressoffice/2013/05/09/executive-order-making-open-and-machine-readable-new-default-government-

Olsen, W. (2012). Data collection: Key debates and methods in social research. London: SAGE Publications Ltd. doi: doi:10.4135/9781473914230.n14

Open data barometer global report 4th ed. (2017). Retrieved July 27, 2017, from http:/ / www.opendatabarometer.org

Open Government Partnership. (2019). Fourth open government national action plan for the United States of America. Retrieved July 8, 2019 from https:/ / open.usa.gov/assets/files/NAP4-fourth-open-government-national-action-plan.pdf

Pradhan, S. (2019). Retrieved from https:/ / www.opengovpartnership.org/wp-content/uploads/2019/06/USA_Letter_Under-Review_January2019.pdf

Reddick, C.G., Chatfield, A.T. \& Puron-Cid, G. (2017). Online budget transparency innovation in government: A case study of the U.S. state governments. Annual International Conference on Digital Government Research (dg.o) '17, June 07-09, 2017, Staten Island, NY, USA 
Right to know law. (2017). Retrieved July 20, 2017, from https://www.nhmunicipal.org/service/right-toknow

RSA 21-R:10-13. (2012). Retrieved July 24, 2017, from http://www.gencourt.state.nh.us/rsa/html/I/21R/21-R-13.htm

Ruijer, E., Grimmelikhuijsen, S., \& Meijer, A. (2017). Open data for democracy: Developing a theoretical framework for open data use. Government Information Quarterly, 34 (1), 45-52. Retrieved from https://doi.org/10.1016/j.giq.2017.01.001

Safarov, I. (2019). Institutional Dimensions of Open Government Data Implementation: Evidence from the Netherlands, Sweden, and the UK. Public Performance \& Management Review, 42(2), 305-328. https://doi.org/10.1080/15309576.2018.1438296

Sieber, R.E. \& Johnson, P.A.(2015) Civic open data at a crossroads: Dominant models and current challenges. Government Information Quarterly, 32: 308-315.

Steinbauer, M., Hiesmair, M., \& Anderst-Kotsis, G. (2016). Making computers understand coalition and opposition in parliamentary democracy. In H. J. Scholl et al. (Eds.), Electronic government: 15th IFIP WG 8.5 International Conference, EGOV 2016, Guimarães, Portugal, September 5-8, 2016, Proceedings (pp. 265-276). Cham: Springer International Publishing. Retrieved from https:/ / doi.org/10.1007/978-3-31944421-5_21 doi: doi:10.1007/978-3-319-44421-5_21

Susha, I., Zuiderwijk, A., Janssen, M., \& Gronlund, A. (2015). Benchmarks for evaluating the progress of open data adoption: Usage, limitations, and lessons learned. Social Science Computer Review, 33 (5), 613-630. Retrieved from https:// doi.org/10.1177/0894439314560852

Thorsby, J., Stowers, G. N. L., Wolslegel, K., \& Tumbuan, E. (2017). Understanding the content and features of open data portals in American cities. Government Information Quarterly, 34(1), 53-61. https://doi.org/10.1016/j.giq.2016.07.001

Ubaldi, B. (2013). OGD: Toward empirical analysis of OGD initiatives. OECD Working Papers on Public Governance(22). doi: doi:10.1787/5k46bj4f03s7-en

Vintar, M., Kunstelj, M., \& Leben, A. (2002). Delivering better quality public services through life-event portals. In Proceedings of the 10th nispacee annual conference: Delivering public services in cee countries: Trends and developments.

Violent crime rate by state. (2017). Retrieved July 22, 2017, from http://www.worldatlas.com/articles/themost-dangerous-states-in-the-u-s.html

Yang, T.-M., Lo, J., \& Shiang, J. (2015). To open or not to open? Determinants of OGD. Journal of Information Science, 41 (5), 596-612. Retrieved from https:/ / doi.org/10.1177/0165551515586715

Yang, T.-M., \& Wu, Y.-J. (2016). Examining the socio-technical determinants influencing government agencies' open data publication: A study in Taiwan. Government Information Quarterly, 33 (3), 378-392.

Yin, R. K. (1994). Case study research: Design and methods. Sage Publications.

Zuiderwijk, A., \& Janssen, M. (2014). Open data policies, their implementation and impact: A framework for comparison. Government Information Quarterly, 31 (1), 17-29. Retrieved from https://doi.org/10.1016/j.giq.2013.04.003 
Zuiderwijk, A., Janssen, M., \& Dwivedi, Y. K. (2015). Acceptance and use predictors of open data technologies: Drawing upon the unified theory of acceptance and use of technology. Government Information Quarterly, 32 (4). https:/ / doi.org/10.1016/j.giq.2015.09.005

\section{About the Authors}

\section{Bonnie Paige}

Bonnie Paige is a Social Sciences Librarian at Colby College. Her research interests include open government data and open scholarship. She received an MLIS from University of British Columbia in 2017.

\section{Luanne Freund}

Luanne Freund is an Associate Professor at the School of Information at the University of British Columbia in Canada, where she has served as Director since 2015. She is a partner in the UBC Designing for People research cluster and teaches and conducts research in the areas of information retrieval, human information interaction, e-government and open data. 